\title{
Mineral Salt Composition and Secondary Metabolites of Ocimum gratissimum L., An Anti-hyperglycemic Plant
}

\section{Fofie $\mathrm{NBY}^{1 *}$, Kiendrebeogo $\mathrm{M}^{2}$, Coulibaly $\mathrm{K}^{3}$, Sanogo $\mathrm{R}^{4,5}$, Kone-bamba $\mathrm{D}^{1}$}

${ }^{1}$ Faculty of Pharmaceutical and Biological Sciences, University of Félix Houphouët Boigny Cocody Abidjan, 22 BP 747 Abidjan 22, Ivory Coast

${ }^{2}$ Biochemistry Laboratory and Applied Chemistry (LABIOCA), 03 BP 7021 Ouagadougou 03, University of Ouagadougou, Burkina Faso

${ }^{3}$ Faculty of Biological Sciences, University of Péléforo Gon Coulibaly, BP 1328 Korhogo, Ivory Coast

${ }^{4}$ Departement of Traditional Medicine of Bamako, Mali

${ }^{5}$ Faculty of Pharmaceutical Sciences of Bamako, Mali

\begin{abstract}
Diabetes mellitus affects more and more people in poor areas of developing countries. The search for an adequate treatment and within the reach of the population has moved us to select the leaves of Ocimum gratissimum. Phytochemical screening was carried out on one hand, detecting major groups of secondary metabolites, on infused $10 \%$ aqueous and on the other hand minerals salt in point microanalysis dispersive spectrometry. Toxic test was carried out using white mice CF1 type. The phytochemical screening revealed the presence of saponin, sterol and terpenes, alkaloid polyphenols, tannins and flavonoids and especially mucilage. The amounts of total polyphenols and total flavonoids were respectively $11.98 \mathrm{mg} \mathrm{EAG/g}$ and $3.99 \mathrm{mg} \mathrm{EQ} / \mathrm{g}$ of dry extract. The phytochemical screening revealed moisture content of $8.97 \%$, total ash of $8.45 \%$, sulfuric ash of $10.27 \%$ and ash insoluble in hydrochloric acid $0.96 \%$. The presence of $\mathrm{Cu}, \mathrm{Zn}, \mathrm{K}, \mathrm{Ca}$ and $\mathrm{Mg}$ having an important role in glucose metabolism was revealed. The study of acute toxicity showed that the toxic dose could be greater than $3000 \mathrm{mg} / \mathrm{kg}$. Also, the leaves are eaten as human food by some people. The results of the studies indicated that the leaves of Ocimum gratissimum contains minerals and bioactive secondary metabolites that, in combination, may explain their therapeutic uses for treating diabetes mellitus.
\end{abstract}

\section{Keywords: Ocimum gratissimum; Minerals; Phytochemistry}

\section{Introduction}

Herbal medicines are increasingly used for the treatment of metabolic diseases including diabetes. This pathology is spreading at an alarming rate worldwide [1]. Diabetes mellitus is a disease commonly found in all communities, especially those living in developing countries. Diabetes mellitus is steadily increasing and that represent a serious threat to the economy and total discomfort to those suffering from diabetes [2]. The global prevalence of diabetes in 2008 was estimated at $10 \%$ of adults' population over 25 years [3]. The estimated global incidence of diabetes in 2013, and the projection for the year 2035 as given by the International Diabetes Federation (IDF) is 592 million [4].

The World Health Organization (WHO), in its resolution AFR/ RC50/R3 August 31, 2000, recommended and encouraged research and the use of medicinal plants especially in countries where access to modern medicine and conventional treatment is difficult. Also, the drugs of modern medicine may have significant side effects. So the search for antidiabetic medicinal plants used traditionally and with little side effects and toxic free has been undertaken by some researchers N'Guessan [5] and Tra et al. [6] in 2008. The Ocimum gratissimum (Lamiaceae) was selected because of its known properties and its availability to many people in tropical and subtropical regions of Africa, India and Southeast Asia. The plant produces an essential oil, volatile, stored in its leaves and stems. This essential oil is a component of several medicinal preparations [1]. Also, this essential oil is active against several species of bacteria including Escherichia coli and fungi including Trichophyton rubrum [7]. Traditionally, Ocimum gratissimum is used in the treatment of sinusitis, pharyngitis, flu, colds, common cold and canker sores [8]. The leaves of this plant species have coagulant, anti-diarrheal, analgesic and spasmolytic [9,10]. This drug also has an anti-hyperglycemic activity in rats' plasma and in human blood $[9,11]$. So, based on the latter activity of this medicinal plant, this study aimed at finding the chemical constituents responsible for its' anti-hyperglycemic activity in order to use the drug in the treatment management of people having type 2 diabetes.

\section{Materials and Methods}

This study required technical equipments including appliances and organic solvents to carry out the drug tests.

\section{Technical equipment}

This material was supplied by Fisher Scientific (France). It includes a knife grinder Retsch SM 200 type, an oven Memmert brand, adjusted at 800 degrees Celsius, a SELECTA brand sand bath, double boiler Memmert type, a portable laboratory scale Sartorius type, a dryer borosilicate, porcelain capsules flat bottom with spout, an energy dispersive spectrometer coupled with a scanning electron microscope with variable pressure D.C/A.C. (FEG SEM Zeiss Supra 40 VP), an $\mathrm{X}$-ray detector (Oxford Instruments), a microanalyzer platform EDS (Inca Cool Dry, without liquid nitrogen).

\section{Solvents and reagents}

The phytochemical screening of the drug required the use of distilled water, organic solvents and reagents. These are sodium acetate, hydrochloric acid, gallic acid, sulfuric acid, sulfuric acid, hydrochloric alcohol, isoamyl alcohol, ammonia, anhydride acetic, chloroform, ferric chloride, magnesium shavings, formalin, gallic tannin, methanol and quercetin. These reagents and solvents are supplied by Prolabo (VWR, France). They are analytically pure.

*Corresponding author: N'Guessan Bra Yvette Fofie, Faculty of Pharmaceutica and Biological Sciences, University of Félix Houphouët Boigny Cocody Abidjan, 22 BP 747 Abidjan 22, Ivory Coast, Tel: 22508885387; E-mail: yvette.fofie08@yahoo.fr

Received June 20, 2016; Accepted July 13, 2016; Published July 18, 2016

Citation: Fofie NBY, Kiendrebeogo M, Coulibaly K, Sanogo R4,Kone-bamba D (2016) Mineral Salt Composition and Secondary Metabolites of Ocimum gratissimum L., An Anti-hyperglycemic Plant. Nat Prod Chem Res 4: 235 doi:10.4172/2329-6836.1000235

Copyright: (c) 2016 Fofie NBY, et al. This is an open-access article distributed under the terms of the Creative Commons Attribution License, which permits unrestricted use, distribution, and reproduction in any medium, provided the original author and source are credited. 
Citation: Fofie NBY, Kiendrebeogo M, Coulibaly K, Sanogo R4,Kone-bamba D (2016) Mineral Salt Composition and Secondary Metabolites of Ocimum gratissimum L., An Anti-hyperglycemic Plant. Nat Prod Chem Res 4: 235. doi:10.4172/2329-6836.1000235

Page 2 of 7

\section{Collection of the herbal drug}

The herbal drug was the leaves of Ocimum gratissimum L. It was collected in February 2012 in Abengourou, eastern region of Ivory Coast. The drug has been identified by the National Centre of Floristic (CNF) of the University of Félix Houphouët-Boigny. In this floral center, herbal drugs were tagged with the references "Abengourou, February 2012, Fofié $\mathrm{n}^{\circ} 02$ retained for reference purposes.

\section{Drying and extraction}

Drugs were dried in the shade at room temperature and sprayed with crusher Retsch type. Part of the powdered drug has been used for the phytochemical analysis and for the determination of minerals salt composition. The other part was used to prepare an aqueous infused $10 \%$. An aliquot of this infused served to determine for the total polyphenols, total flavonoids. The rest of the extract was used to determine its safety.

\section{Phytochemical screening by color reactions in tube}

The methods used for gratissimum Ocimum L. leaves characterization tests are limited to the detection of large chemical groups with systemic reactions, very sensitive even with a small quantity of drugs. They are only indicative value [12]. The results were classified: Positive reaction: +; abundant: ++; Negative reaction: -.

\section{Searching for polyphenols by ferric chloride test $\left(\mathrm{FeCl}_{3}\right)$}

Polyphenols are compounds which have several phenol groups. Colorimetry phenols highlights, complex formation (selective complexassions) with ferric ion. The coloring of the complexed ion is greenish, blackish-blue or blackish-brown.

Procedure: From each aliquot were taken two $\mathrm{mL}$ and was added one drop of alcoholic solution of $2 \%$ ferric chloride. Ferric chloride in the presence of polyphenol derivatives produces the appearance of a greenish, blackish-blue or blackish-brown color.

\section{Searching for tannins through the test of Stiasny}

The tannins are composed of two subgroups the gallic tannins derivative of gallic acid and combined as hydrolysable glycosides, and tannins catechin non hétérosidique kind which are formed of catechols polymers condensed form. Their characterization is done by the Stiasny reagent (mixture of formaldehyde and concentrated hydrochloric acid). Catechin tannin, (in condensed form, not hydrolyzed) is precipitated as a brown flake by heating and cooling, whereas gallic tannins (hydrolysable glycosides) are hydrolysed after addition of sodium acetate. The addition of a few drops of $3 \% \mathrm{FeCl}_{3}$ give a greenish color or specific blue-black color to polyphenols indicating the presence of gallic tannins.

Procedure: Searching for catechin tannins (Stiasny reaction): Evaporate each extract to dryness in a $5 \mathrm{~mL}$ capsule. Add to residue 15 $\mathrm{mL}$ Stiasny reagent. Keep the mixture in water bath at $80^{\circ} \mathrm{C}$ for $30 \mathrm{~min}$. Let cool. The observation of precipitates in large flakes in this solution characterizes the catechin tannins (tannins not hydrolyzed).

Searching for gallic tannins: Filter each previous solution. The filtrate was collected and saturated with sodium acetate. The addition of 3 drops of $3 \%$ ferric chloride d causes the appearance of an intense blueblack coloration indicating the presence of gallic tannins (hydrolysable tannins) not precipitated by the reagent Stiasny.

\section{Determination of flavonoids by Shibata reaction}

Flavonoids are yellow pigments widely distributed in plants. They exist as glycosides which genin drift benzogammapyrone core. Their characterization is done after hydrolysis with hydrochloric alcohol solution. The action of magnesium ion on the genin, results in the formation of a compound: cyanidin chloride which has a pink-orange color or red-purple.

Procedure: evaporate each solution to dryness in a $2 \mathrm{~mL}$ capsule. After cooling, obtain the residue with $5 \mathrm{~mL}$ of hydrochloric alcohol $(1: 1 \mathrm{v} / \mathrm{v})$. Pour the solution into a test tube and add 2 to 3 magnesium shavings (complexing agent flavonoids). The orange-pink or violet observed indicate the presence of flavonoids. The addition of 3 drops of isoamyl alcohol intensifies this coloring.

\section{Searching for free quinone substances or combined by the reaction of Borntraëger}

Characterization of quinone substances is based on the fact that they give under the action of an alkaline solution (aqueous ammonia, soda, lime water) a cherry red color. The test consisted of proceeding immediately to the hydrolysis of genins to characterize the total quinone substances.

Procedure: In a capsule, evaporated to dryness, $2 \mathrm{~mL}$ aliquot of each. Triturate the residue in $5 \mathrm{ml}$ of hydrochloric acid 1/5. In a test tube, bring the solution, a half hour, a boiling water bath. After cooling on a cold water stream, extracting the hydrolyzate with $20 \mathrm{~mL}$ of chloroform in a test tube. Collect the chloroform phase in a test tube and add $0.5 \mathrm{~mL}$ of Borntraeger reagent (ammonia diluted to one half). The appearance of a color ranging from red to violet indicates the presence of quinones.

\section{Searching for sterols, steroids and terpenes by Liebermann reaction}

In the presence of concentrated sulfuric acid or Liebermann reactive, sterols and terpenes give a red-brown color.

Procedure: The extract hot and dry aliquot was obtained by acetic anhydride $1 \mathrm{~mL}$ chloroform (1: $1 \mathrm{v} / \mathrm{v})$. This solution was divided between two test tubes numbered 1 and 2 . In the test tube $2,0.5 \mathrm{~mL}$ of concentrated sulfuric acid was poured along the wall of the tube very carefully. The appearance at the interphase of a purple or purple ring indicates a positive reaction.

\section{Searching for saponosides}

The saponins dissolve in water. They form a persistent foam solution by stirring. This property of saponosides solutions is used to highlight their presence.

$$
\text { Foam index }=\left(1 / n^{\circ} \text { tube }\right) \times 100
$$

Procedure: In a series of 10 test tubes of $16 \mathrm{~mm}$ diameter and 16 $\mathrm{cm}$ height and each numbered from 1 to 10 , the aliquots were divided successively from 1 to $10 \mathrm{~mL}$. These volumes were adjusted in each tube to $10 \mathrm{~mL}$ with distilled water. Each tube was shaken in lengthwise for 15 seconds at 2 shakes per second ( 30 agitations). After 15 minutes, the foam height was measured in each tube. The tube in which the height of the foam was persistent and equal to $1 \mathrm{~cm}$ indicates the value of the foam index according to the following report, with $\mathrm{n}^{\circ}$ the number of the tube. 
Citation: Fofie NBY, Kiendrebeogo M, Coulibaly K, Sanogo R4,Kone-bamba D (2016) Mineral Salt Composition and Secondary Metabolites of Ocimum gratissimum L., An Anti-hyperglycemic Plant. Nat Prod Chem Res 4: 235. doi:10.4172/2329-6836.1000235

Page 3 of 7

\section{Searching for alkaloids}

Alkaloids have the property of combining with heavy metals (iodine, bismuth, mercury) and precipitates as colored heavy salts. The Dragendorff reagent (reagent potassium iodobismuthate) was used for their characterization.

Procedure: In a capsule, $6 \mathrm{~mL}$ of each solution was evaporated to dryness. The residue was taken up by $6 \mathrm{ml}$ of alcohol at $60^{\circ} \mathrm{C}$ in a test tube. In the presence of 2 drops of Dragendorff reagents, it appears precipitates or red-orange color.

\section{Searching for mucilage}

Characterization of mucilages is through the action of alcohol. Thereof in the presence of ethanol, form flakes which precipitate.

Procedure: 1 milliliter $(\mathrm{mL})$ of each aliquot, in a test tube, was mixed with $3 \mathrm{~mL}$ of methanol at 60 alcoholic degrees. After stirring, flocculent precipitate indicates the presence of mucilage in the drug.

\section{Measurement}

The presence of various secondary metabolites gives us the possibility of assessing the value of the drug. That of moisture content gives storability and the ash content makes it possible firstly to assess the extraction rate and partly to the presence of inorganic compounds.

Total polyphenols: All the phenolic compounds present in each extract was measured [13]. The method used was based on the reduction of reactive phospho-tungstic-molybdo or Folin-Ciocalteu (FCR) by polyphenols present in solution.

Method: Each sample to be tested is dissolved in a methanol-water $(90: 10, \mathrm{v} / \mathrm{v})$ so as to obtain a concentration of $10 \mathrm{mg} / \mathrm{mL}$. Then, this stock solution is diluted to $1 / 10^{\text {th }}(1 \mathrm{mg} / \mathrm{mL})$ with distilled water. A volume of $125 \mu \mathrm{L}$ of diluted solution was mixed with $625 \mu \mathrm{L}$ of FolinCiocalteu reagent $(0.2 \mathrm{~N})$, then incubated for 5 minutes. Then, $100 \mu \mathrm{L}$ of an aqueous solution of sodium hydrogencarbonate $\left(\mathrm{HCO}_{3} \mathrm{Na}\right)$ at 75 $\mathrm{g} / \mathrm{L}$ are added and then mixed by vortexing. The mixture was incubated for 2 hours. After incubation, the absorbance was measured at $760 \mathrm{~nm}$ using a spectrophotometer. Three tests are carried out for each extract. The reading was made against a blank consisting of a mixture of 0.5 $\mathrm{mL}$ of $\mathrm{FCR}$ and $1 \mathrm{~mL}$ of $\mathrm{HCO}_{3} \mathrm{Na}$. The total polyphenol contents are determined using a straight calibration of gallic acid $(0-200 \mathrm{mg} / \mathrm{L}$ by the equation $\mathrm{Y}=0.005^{\star} \mathrm{X}+0.0885 ; \mathrm{R}^{2}=1$ ) (Figure 1). The result, in $\mathrm{mg} /$ Gallic Acid Equivalent in $100 \mathrm{mg}$ of extract (GAE mg/100 mg extract) is determined by the following formula:

$$
C=\frac{c \times D}{C i} \times 100
$$

C: total polyphenol concentration of sample expressed in GAE $\mathrm{mg} / 100 \mathrm{mg}$ of extract.
c: read concentration of the sample
D: dilution factor
Ci: initial concentration of the stock solution in $\mathrm{mg} / \mathrm{mL}$.

\section{Measurement of total flavonoids}

The levels of total flavonoids in the extracts were measured by the colorimetric method [14].

Method: A volume of $75 \mu \mathrm{L}$ of $2 \% \mathrm{AlCl}_{3}$ in pure methanol is mixed with an equal volume of extract to $1 \mathrm{mg} / \mathrm{mL}$ in methanol. Optical densities were read after 10 minutes at $415 \mathrm{~nm}$ using the spectrophotometer. Quercetin $(0-100 \mathrm{mg} / \mathrm{L})$ was used as the standard for the development of the calibration curve $\left(\mathrm{Y}=0.0251+0.0885^{\star} \mathrm{X}\right.$; $\mathrm{R}^{2}=0.99$ ) (Figure 2). A mixture of $75 \mu \mathrm{L}$ of extract and $75 \mu \mathrm{L}$ of methanol without $\mathrm{AlCl}_{3}$ was used as white. A total of three (3) analyzes are performed for each sample and the given result was an average of three readings. The results are expressed in milligrams Quercetin equivalent of $100 \mathrm{mg}$ of dry extract (mg QE/100 mg).

$$
\begin{aligned}
& C=\frac{c \times D}{C i} \times 100 \\
& \text { C=Quercetin Equivalent Value in } \mathrm{mg} \text { in } 100 \mathrm{mg}
\end{aligned}
$$

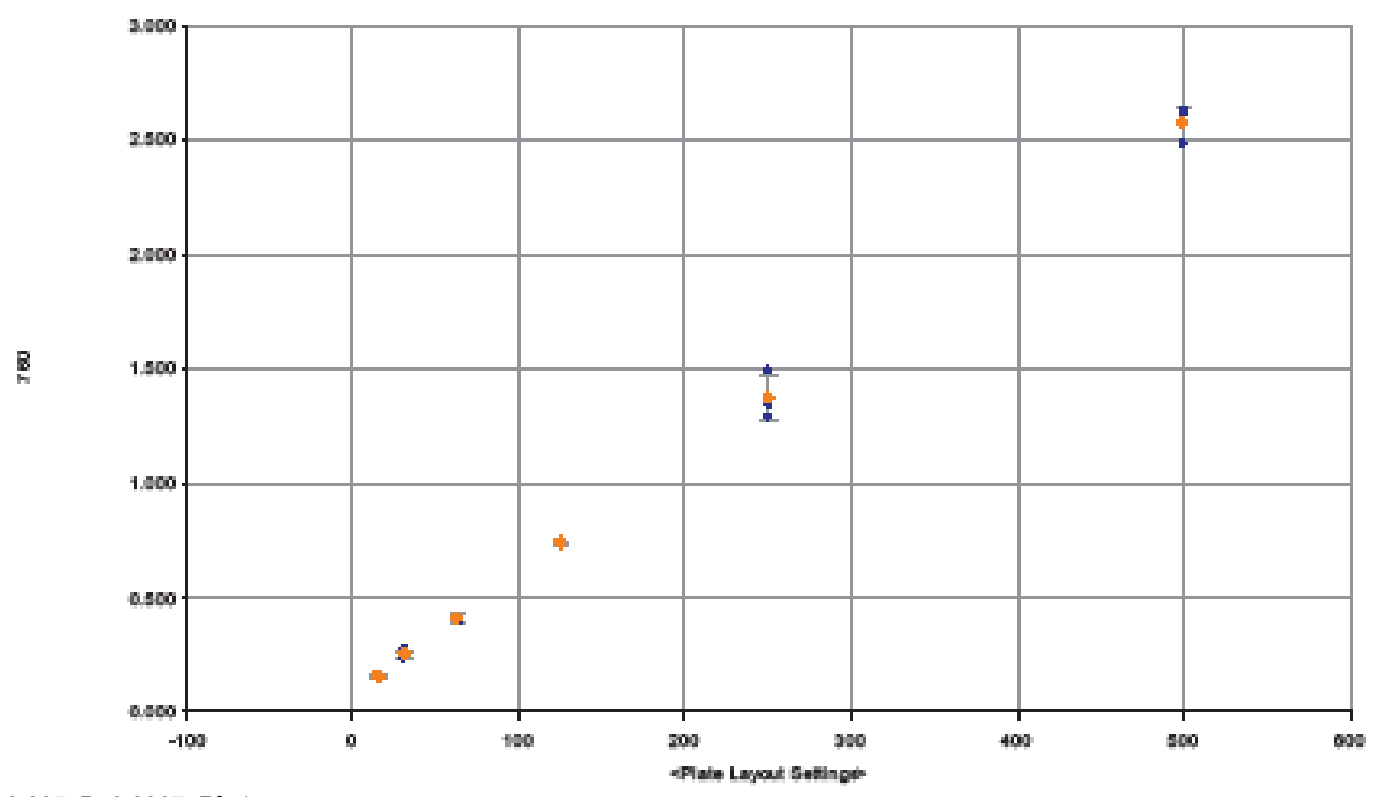


Citation: Fofie NBY, Kiendrebeogo M, Coulibaly K, Sanogo R4,Kone-bamba D (2016) Mineral Salt Composition and Secondary Metabolites of Ocimum gratissimum L., An Anti-hyperglycemic Plant. Nat Prod Chem Res 4: 235. doi:10.4172/2329-6836.1000235

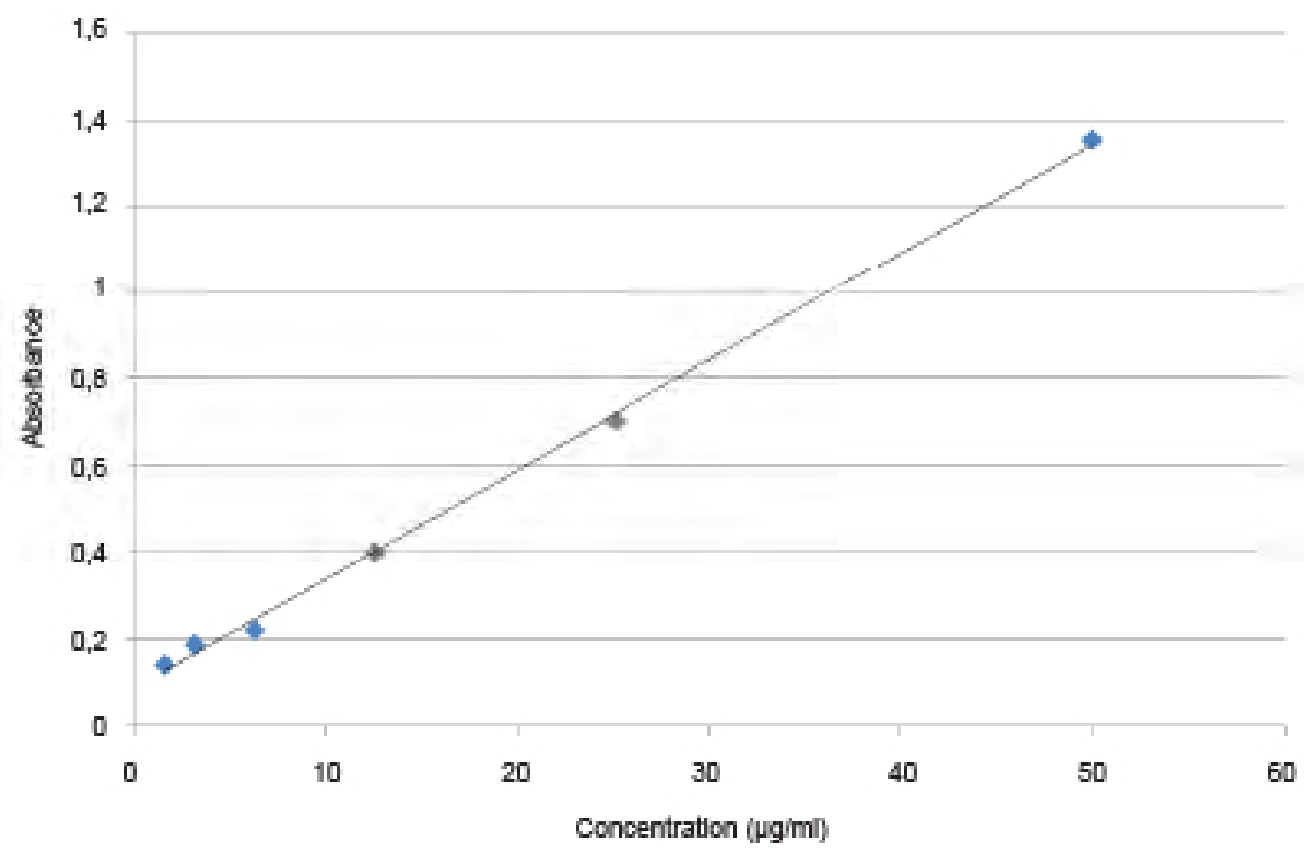

$\mathrm{Y}=0.0251 \times \mathrm{X}+0.0885$ avec $\mathrm{R}^{2}=0.9985$

Figure 2: Standard curve of quercetin $(415 \mathrm{~nm})$ for total flavonoids.

$\mathrm{c}=$ Read concentration of the sample $(\mathrm{Q} E \mathrm{mg} / \mathrm{L})$ on the standard curve

$\mathrm{D}=$ Dilution factor of sample under measurement

$\mathrm{Ci}=$ Initial concentration of the sample solution to be measured

\section{Determination of ash}

Total ash: This is the amount of non-volatile residual substance obtained after complete calcination of the drug.

Procedure: $3 \mathrm{~g}$ of powder of each drug for analysis was put into 3 previously marked crucibles and placed in the oven at $600^{\circ} \mathrm{C}$ for 24 hours. The crucibles were reweighed after cooling. The results were given by the following formula:

$$
C(\%)=\frac{M C}{P E} \times 100
$$

$\mathrm{C}=$ Total ash

$\mathrm{PE}=$ Mass of the test sample

$\mathrm{MC}=$ Mass of ash=Mass after oven-mass before the oven.

\section{Ash insoluble in hydrochloric acid}

Principle: the measurement of ash insoluble in hydrochloric acid (CC) quantifies the external compound (dirt, sand) or own plants (calcium concretion) contained in the drug.

Procedure: The $10 \%$ hydrochloric acid $(20 \mathrm{~mL})$ was placed on the total ash obtained. This mixture was heated in a water bath for 15 minutes. The insoluble residue in water after filtration was washed. The filter paper containing the residue was transferred into a caliberated crucible and placed in a furnace at $800^{\circ} \mathrm{C}$ for 3 hours. After cooling the crucible was weighed again. The following formula was used to calculate the percentage of hydrochloric ashes.

$$
\begin{aligned}
& C C(\%)=\frac{C}{P E} \times 100 \\
& \text { CC=Ash insoluble in hydrochloric acid } \\
& \mathrm{C}=\text { Total ash obtained } \\
& \mathrm{PE}=\text { Mass of the test sample }
\end{aligned}
$$

\section{Sulphuric ashs} drugs.

Principle: It quantifies the inorganic substances contained in

Procedure: In a marked crucible, $3 \mathrm{~g}$ of drug powder were soaked with concentrated sulfuric acid diluted to one half with water. The crucible was placed in an oven at $800{ }^{\circ} \mathrm{C}$ for 6 hours. After cooling in a desiccator, the whole was weighed. The following formula was used to calculate the percentage of sulfuric ash.

$$
\begin{aligned}
& C S(\%)=\frac{M C}{P E} \times 100 \\
& \text { CS=Sulphuric ash } \\
& \mathrm{PE}=\text { Mass of the test sample }
\end{aligned}
$$

$\mathrm{MC}=$ mass sulfuric ash=mass of the drug moistened with concentrated sulfuric acid diluted to one half with water before ovenmass after oven.

\section{Measurement of mineral salts}

The qualitative and quantitative analysis of minerals are made using punctual microanalysis by energy dispersive spectrometry coupled with Scanning Electron Microscope/Energy Dispersion Spectrometry (SEM/EDS), variable pressure DC/AR (SEM FEG Zeiss Supra 40 VP). This device is equipped with an X-ray detector (Oxford Instruments) connected to a micro analyzer platform EDS (Inca Cool Dry, without liquid nitrogen). 
Citation: Fofie NBY, Kiendrebeogo M, Coulibaly K, Sanogo R4,Kone-bamba D (2016) Mineral Salt Composition and Secondary Metabolites of Ocimum gratissimum L., An Anti-hyperglycemic Plant. Nat Prod Chem Res 4: 235. doi:10.4172/2329-6836.1000235

Page 5 of 7

Procedure: Two grams of sample was incinerated (ASTM D 482), then cooled in a dryer. Then $10 \mathrm{mg}$ of ash are homogeneously spread with double-sided adhesive carbon onto a primed pad and attached to the object holder of SEM/EDS. The whole was introduced into the SEM chamber for microanalysis-RX (EDS). The desired minerals are primarily calcium, chromium, magnesium, manganese, sodium, potassium and zinc.

Results are proportions, averages of three trials.

\section{Toxicity}

Laboratory animals used were mice. These mice had characteristics of vigor and productivity called CF1 (Carworth Farms Strain 1) male and female, aged 8 to 10 weeks. The international ethical standards on the use of laboratory animals were observed [15].

Principle: The acute toxic studies have been carried out [15] in accordance with OECD guidelines - 423. sought acute signs are apathy, excitement, breathing disorders, grooming excessive, denial of food and/or drink, oral bleeding and/or nasal, abdominal pain (writhing), diarrhea, tremor, convulsions, coma and/or death.

This method allows the estimation of toxicity, and the results used to classify a substance for acute toxicity, according to the Globally Harmonized System of Classification and Labeling of Chemicals.

A maximum single dose is administered to a batch of 3 mice for each extract. Two cases are possible: If there's death, the second group receives a lower dose. If they are living the second group receives a higher dose. The animals are observed with special attention during the first 4 hours then daily, then a total of 14 days.

Procedure: For each drug, three mice $(n=3)$ of both sexes, randomly selected, were used. Animals were fasted for $4 \mathrm{~h}$, only, free access to water. The test extract was administered by gavage to the maximum dose of $3000 \mathrm{mg} / \mathrm{Kg}$. The mortality and signs of toxicity were sought for 3 days (or 14 days time limit for seeking acute toxicity) and noted. The mortality observed in $2 / 3$ or $3 / 3$ animals, leads to consider the dose administered as a toxic dose. If mortality is observed in one out of three mice animals, the same dose is administered again for another batch to confirm the toxic effect. If no mortality is observed, the procedure is then repeated with extracts of doses higher plants.

\section{Results and Discussion}

\section{Major chemical constituents}

The phytochemical screening of the herbal drug showed the presence of all major chemical groups. The present study sought more secondary metabolites; minerals salt contained in Ocimum gratissimum leaves that may explain the anti-hyperglycemic activity of this medicinal plant. It also assessed the toxicity of the aqueous infused.

Regarding the composition secondary metabolites of the drug collected in Ivory Coast, West Africa, phytochemical screening showed the main chemical constituents, total alkaloids, saponins, polyphenols, tannins and flavonoids and terpenes sterols and the presence of mucilage except quinone substances (Table 1). These results confirm those found by N'Guessan [16]. Also the presence of mucilage reported in Abelmoschus esculentus Moench (Malvaceae) by a study by Masashi [17], showed a glucose lowering activity in mice.

The intensity of coloration during when phytochemical screening and the importance of total polyphenols and total flavonoids in particular led to measuring them.

\section{Determination of total polyphenols and total flavonoids}

The total polyphenol content in the aqueous totum is $11.98 \pm 0.07$ $\mathrm{mg} \mathrm{GAE} / \mathrm{g}$ dry matter, while the total flavonoid content is $3.99 \pm 0.57$ $\mathrm{mg} \mathrm{QE} / \mathrm{g}$ dry matter.

These values are close to those found in Euphorbia hirta L. respectively GAE $12.1 \mathrm{mg} / \mathrm{g}$ and $4.14 \mathrm{mg} \mathrm{QE} / \mathrm{g}$ [11]. These compounds could participate in the anti diabetic activity of the drug; diabetes is part of metabolic diseases and favorably influenced by the polyphenolic compound [18].

In the presence of these secondary metabolites in the plant, are also found other compounds that are among other minerals. Minerals are essential elements involved in many mechanisms. They are supplied by food or medication.

Seeking explanation for the anti-hyperglycemic activity of the plant has led to our search for micronutrients such as trace elements, involved in glucose metabolism [19]. This research has uncovered many minerals (Tables 2 and 3) including magnesium, an enzyme activator which is involved in major metabolic pathways in the body and increases the secretion of insulin [20]; potassium, major ion of positive charge in the cells of the organism participates in inter alia the manufacture of glycogen and secretion of hormones including insulin [21]; calcium, an intracellular second messenger in insulin hormone response [22], copper, an essential antioxidant in the body and nutrient coenzyme zinc, are supporting a good insulin activity, [19], without forgetting the Manganese [23].

Given the properties that Ocimum gratissimum present, and for its secondary metabolites compositions, for its various pharmacological properties, especially against the installation of diabetes [11], a phytochemical analysis was also conducted.

Vegetables are rich in water. The proportion of this water ranges from $60 \%$ to $80 \%$ depending on the organ of the plant. Drugs are well preserved when the content of the water is less than or equal to $10 \%$ [12]. In this study, the powder of dried leaves of Ocimum gratissimum L. have a moisture content of $8.97 \%$ less than $10 \%$.

The value of ash gives an idea of the inorganic composition or other impurities in the drug [24]. The value of Ocimum gratissimum L. total ash is $8.45 \%$ close to those of Bihari [25] who found $8.7 \%$ while the sulfuric acid ash differ $10.27 \%$ vs $3.7 \%$ [25]. This could be because of the nature of soil on which the plant was grown.

On toxicity, Ocimum gratissimum is not toxic to $3000 \mathrm{mg} / \mathrm{kg}$ bw for rats. These results are consistent with data reported by some authors, it is good to note that this drug is consumed as food or spice in Nigeria, Togo and Côte d'Ivoire $[8,10]$.

\begin{tabular}{|c|c|c|c|c|c|c|c|c|c|c|}
\hline \multirow{2}{*}{ Ext } & \multirow{2}{*}{ Stérol-Terpène } & \multirow{2}{*}{ Poly-phénols } & \multirow{2}{*}{ Flav } & \multicolumn{2}{|c|}{ Tanins } & \multirow{2}{*}{ Quinones } & \multirow{2}{*}{ Alc. } & \multirow{2}{*}{ Sap } & \multirow{2}{*}{ Form Index (\%) } & \multirow{2}{*}{ Muc } \\
\hline & & & & G & C & & & & & \\
\hline Infused & + & + & + & - & + & - & + & + & 12.5 & ++ \\
\hline
\end{tabular}

Mineral elements

Table 1: Phytochemical screening of infused Ocimum gratissimum $\mathrm{L}$. 
Citation: Fofie NBY, Kiendrebeogo M, Coulibaly K, Sanogo R4,Kone-bamba D (2016) Mineral Salt Composition and Secondary Metabolites of Ocimum gratissimum L., An Anti-hyperglycemic Plant. Nat Prod Chem Res 4: 235. doi:10.4172/2329-6836.1000235

Page 6 of 7

\begin{tabular}{|c|c|c|c|c|c|c|c|c|c|c|c|c|c|c|c|}
\hline Spectrum & In stats. & $\mathrm{Na}$ & Mg & Si & $\mathbf{P}$ & $\mathbf{s}$ & $\mathrm{Cl}$ & $\mathrm{K}$ & $\mathrm{Ca}$ & $\mathrm{Fe}$ & $\mathrm{Cu}$ & $\mathrm{Zn}$ & At & 0 & Total \\
\hline Spectrum 1 & Yes & 0.25 & 4.13 & 0.40 & 4.75 & 0.56 & 9.34 & 29.55 & 23.53 & 0.16 & 0.53 & 0.20 & 0.72 & 25.89 & 100.00 \\
\hline Spectrum 2 & Yes & 0.27 & 4.27 & 0.52 & 4.66 & 0.42 & 9.41 & 29.11 & 24.13 & 0.13 & 0.35 & 0.03 & 0.86 & 25.85 & 100.00 \\
\hline Spectrum 3 & Yes & 0.29 & 4.23 & 0.49 & 4.90 & 0.56 & 9.73 & 27.82 & 24.31 & 0.08 & 0.37 & 0.17 & 0.89 & 26.16 & 100.00 \\
\hline Mean & & 0.27 & 4.21 & 0.47 & 4.77 & 0.51 & 9.49 & 28.83 & 23.99 & 0.12 & 0.42 & 0.13 & 0.82 & 25.97 & 100 \\
\hline Std. deviation & & 0.02 & 0.07 & 0.06 & 0.12 & 0.08 & 0.21 & 0.9 & 0.41 & 0.04 & 0.1 & 0.09 & 0.09 & 0.17 & \\
\hline Max. & & 0.29 & 4.27 & 0.52 & 4.9 & 0.56 & 9.73 & 29.55 & 24.31 & 0.16 & 0.53 & 0.2 & 0.89 & 26.16 & \\
\hline Min. & & 0.25 & 4.13 & 0.4 & 4.66 & 0.42 & 9.34 & 27.82 & 23.53 & 0.08 & 0.35 & 0.03 & 0.72 & 25.85 & \\
\hline
\end{tabular}

Table 2: Mineral salt composition in percentage of weight in the drug (leaves) of Ocimum gratissimum L.

\begin{tabular}{|c|c|c|c|c|c|c|c|c|c|c|c|c|c|c|}
\hline Spectrum & In stats. & $\mathrm{Na}$ & Mg & Si & $\mathbf{P}$ & $\mathbf{s}$ & $\mathrm{Cl}$ & $\mathrm{K}$ & $\mathrm{Ca}$ & $\mathrm{Fe}$ & $\mathrm{Cu}$ & $\mathrm{Zn}$ & At & Total \\
\hline Spectrum 1 & Yes & 0.34 & 6.84 & 0.85 & 10.87 & 1.41 & 0 & 35.59 & 32.92 & 0.21 & 0.67 & 0.24 & 0 & 89.94 \\
\hline Spectrum 2 & Yes & 0.36 & 7.07 & 1.11 & 10.67 & 1.05 & 0 & 35.07 & 33.76 & 0.17 & 0.44 & 0.04 & 0 & 89.73 \\
\hline Spectrum 3 & Yes & 0.39 & 7.01 & 1.05 & 11.23 & 1.4 & 0 & 33.51 & 34.01 & 0.1 & 0.47 & 0.21 & 0 & 89.38 \\
\hline Mean & & 0.36 & 6.98 & 1.00 & 10.92 & 1.29 & 0.00 & 34.72 & 33.56 & 0.16 & 0.52 & 0.17 & 0.00 & 89.68 \\
\hline Std. deviation & & 0.02 & 0.12 & 0.14 & 0.28 & 0.21 & 0.00 & 1.08 & 0.57 & 0.06 & 0.12 & 0.11 & 0.00 & \\
\hline Max. & & 0.39 & 7.07 & 1.11 & 11.23 & 1.41 & 0.00 & 35.59 & 34.01 & 0.21 & 0.67 & 0.24 & 0.00 & \\
\hline Min. & & 0.34 & 6.84 & 0.85 & 10.67 & 1.05 & 0.00 & 33.51 & 32.92 & 0.10 & 0.44 & 0.04 & 0.00 & \\
\hline
\end{tabular}

Scanning ash in Ocimum gratissimum enable to discover many minerals and gases with Magnesium, Potassium, Calcium, Zinc and Copper Table 3: Proportion (\%) of mineral salt in the drug (leaves) of Ocimum gratissimum $\mathrm{L}$.

\section{Conclusion}

Searching for the various compositions of Ocimum gratissimum has helped to better understand the normal glycemic activity of this plant. Indeed the simultaneous presence of mucilage, secondary metabolites and minerals salts exerts a synergistic action to reduce hyperglycemia and undertakes remedial action due to the presence of polyphenolic compounds including flavonoids. It is also desirable to encourage people in developing countries to consume more the leaves of Ocimum gratissimum in view of the galloping installation of diabetes mellitus in our communities.

\section{References}

1. Pessoa ML, Morais MS, Bevllaqua LMC, Luciano SHJ (2002) Anthelmintic activity of essential oil of Ocimum gratissimum Linn. and eugenol against Haemonchuscontortus. Veterinary Parasitology 109: 59-63. 
Citation: Fofie NBY, Kiendrebeogo M, Coulibaly K, Sanogo R4,Kone-bamba D (2016) Mineral Salt Composition and Secondary Metabolites of Ocimum gratissimum L., An Anti-hyperglycemic Plant. Nat Prod Chem Res 4: 235. doi:10.4172/2329-6836.1000235

Page 7 of 7

2. Oga ASS, Tebi A, Aka J, Adouéni KV, et al. (2006) Le diabète sucré diagnostiqué en Côte d'Ivoire: des particularités épidémiologiques. Médecine Tropicale 66: 241-246.

3. Patel DK, Prasad SK, Kumar R, Hemalatha S (2012) An overview on antidiabetic medicinal plants having insulin mimetic property. Asian Pacific Journal of Tropical Biomedicine: 320-330.

4. IDF Diabetes Atlas Group (2013) Update of mortality attributable to diabetes for the IDF Diabetes Atlas: Estimates for the year 2011. Diabetes research and clinical practice 100: 277-279.

5. N'Guessan K (2008) Plantes médicinales et pratiques médicales traditionnelles chez les peuples Abbey et Krobou du Département d'Agboville (Côte-d'Ivoire). Thèse de Doctorat ès Sciences Naturelles. Université de Cocody-Abidjan, UFR Biosciences, Laboratoire de Botanique, p: 235.

6. Tra BFH, Irié GM, N'gaman KCC, Mohou CHB (2008) Études de quelques plantes thérapeutiques utilisées dans le traitement de l'hypertension artérielle et du diabète: deux maladies émergentes en Côte d'Ivoire. Sciences \& Nature 5: $39-48$

7. Lopez P, Sanchez K, Batlle R, Nerin C (2005) Solid and vapor phase antimicrobial activities of six essential oils susceptibility of selected food borne bacterial and fungal strains. Journal of Agricultural and Food Chemistry 53 6939-6946.

8. Ake Assi L (2011) Abstract medical and African pharmacopoeia: some plants traditionally used in the coverage of primary health care. Abidjan, p: 157.

9. Aguiyi JC, Obi Cl, Gang SS, Igweh AC (2000) Hypoglycemic activity of Ocimum gratissimum in rats. Fitoterapia 71: 444-446.

10. Edemeka DBU, Ogwu AS (2000) Blood coagulation activities of leaf extracts of Ocimum gratissimum plant in man. Journal of Herbs, Spices and Medicinal Plants 7: 9-14.

11. Fofie NBY (2014) Contribution à l'étude botanique, phytochimique et pharmacodynamique de plantes utilisées en médecine traditionnelle africaine: Euphorbia hirta L. (Euphorbiaceae), Ocimum gratissimum L. (Lamiaceae), Sorghum bicolor (L.) Moench. (Poaceae) et Ziziphus mauritiana Lam. (Rhamnaceae). Thèse Unique. Université Félix Houphouët Boigny, U.F.R. Sciences Pharmaceutiques and Biologiques, Laboratoire de Pharmacognosie. Botanique and Cryptogamie, p: 322.

12. OUA (1988) Organisation de l'unité africaine/commission scientifique technique et de la recherche (OUA/CSTR), Pharmacopée africaine. Méthodes générales d'analyses. Première (Ed) Lagos, Nigéria, p: 254
13. Lamien-Meda A, Lamien CE, Compaore MMY, Meda RNT et al. (2008) Polyphenol content and antioxidant activity of fourteen wild edible fruits from Burkina Faso. Molecules 13: 581-594

14. Arvouet-Grand A, Vennat B, Pourrat A, Legret P (1994) Standardization of propolis extract and identification of principal constituents. J Pharm Belg 49: 462-468.

15. Ecobichon DJ (2001) Pesticide use in developing countries. Toxicology 160: 27-33.

16. N'Guessan K, Kadja B, Zirihi G, Traoré D et al. (2009) Screening phytochimique de quelques plantes médicinales ivoiriennes utilisées en pays Krobou (Agboville, Côte-d'Ivoire). Sciences \& Nature 6: 1-15.

17. Masashi T, Shimizu N, Oshima Y, Takahashi M, et al. (1987) Hypoglycemic activity of twenty plant mucilages and three modified products. Planta Med 53 8-12.

18. N'Guessan AHO, Déliko CED, Mamyrbékova-Bekro JA, Békro YA (2011) Teneur en composés phénoliques de 10 plantes médicinales employées dans la tradithérapie de l'hypertension artérielle, une pathologie émergente en Côte d'Ivoire. Rev de Génie industriel 6: 55-56.

19. Lefèvre PJ, Scheen AJ (1995) Improving the action of insulin. Clin Invest Med 1: $340-347$.

20. Voma C, Romani AMP (2014) Role of Magnesium in the Regulation of Hepatic Glucose Homeostasis.

21. Jacques PF, Cassidy A, Rogers G, Peterson JJ, et al. (2013) Higher Dietary Flavonol Intake Is Associated with Lower Incidence of Type 2 Diabetes. Journal of Nutrition 143: 1474-1480.

22. Ouazara MA, Amineb M, Harifia G, Ouilkia I et al. (2010) Evaluation of the calcium intake in population of Marrakesh and its region: 1000 cases. Annales d'Endocrinologie 71: 51-55.

23. Lee SH, Jouihan HA, Cooksey RC, Jones D, et al. (2013) Manganese supplementation protect against diet-induced diabetes in wild type mice by enhancing insulin secretion. Endocrinology 154: 1029-1038.

24. African Pharmacopoeia (1986) General Methods for Analysis. 1st edn. Lagos (OAU/STRC) 2: 128-139.

25. Bihari CG, Manaswini B, Kumar JP, Kumar TS (2012) Pharmacognostical and phytochemical investigation of various tulsi plants available in south eastern odisha. International Journal of Research in Pharmaceutical and Biomedical sciences 2: 605-610. 